\title{
Dichlorvos and Paraquat induced spatial avoidance response: A more realistic determinant of population decline of Oreochromis niloticus
}

\author{
Soriwei, E.T., Umeokeke, H.C.*, Amaeze, H.N., Ogunfeitimi, O.O. \& Labinjo, A.S. \\ Ecotoxicology Laboratory, Ecotoxicology and Conservation Unit, Department of Zoology, \\ University of Lagos, Akoka-Yaba, Lagos, Nigeria.
}

Received April 19, 2021; Accept September 13, 2021

\begin{abstract}
The present study evaluated the ability of Dichlorvos and Paraquat to provoke avoidance response in fingerlings of Nile tilapia Oreochromis niloticus and estimate the population immediate decline (PID). The non-forced multi-compartmented system used for non-forced assays, were constructed to allow free movement of fishes along six compartments. Fishes ( $\mathrm{n}=3$ per compartment/treatment, totaling 18 per system) were exposed to a gradient of Dichlorvos (1.0, 2.0, 4.0, 5.0 and 6.0 $\left.\mathrm{mg} \mathrm{L}^{-1}\right)$ and Paraquat $\left(10.0,30.0,50.0,70.0,100.0 \mathrm{mg} \mathrm{L}^{-1}\right)$ and their distribution were recorded at $20 \mathrm{~min}$ interval for a 3-h period. Mortalities recorded in forced exposures were $17 \%$ and $0 \%$ at lowest concentrations and, $67 \%$ and $83 \%$ at highest concentrations for Dichlorvos and Paraquat correspondingly. For non-forced exposure, fishes presented a significant $(p<0.005)$ gradient-dependent spatial avoidance for both pesticides after 3-h. They avoided the lowest concentrations of Dichlorvos and Paraquat $\left(1.0\right.$ and $\left.10.0 \mathrm{mg} \mathrm{L}^{-1}\right)$ by $40 \%$ and $90 \%$ respectively and $100 \%$ at the highest concentrations for both pesticides. The PID was driven by avoidance behavior rather than mortality. This result indicates that the dangers of pesticide contamination is not only in their toxicity to organisms, but also, in habitat selection processes by organism resulting in serious environmental turbulence.
\end{abstract}

Key words: Environmental risk assessment; Non-forced exposure; Forced exposure; Pesticides; Population Immediate Decline; Spatial avoidance.

\section{INTRODUCTION}

Agricultural practices which significantly intensified since the 1960s came with increased use of external farm input such as synthetic fertilizers and diverse pesticides in order to boost productivity (Tilman et al., 2001). However, this development came at a cost as the ecosystem services that improved the wellbeing of man were greatly impacted (Majeed, 2018). Pesticide use was one of the most concerning aspect of agricultural revolution, due to their deleterious effects on biota at the different levels of organization (Majeed, 2018). The Food and Agricultural Organization and World Health Organization defined pesticides as chemical substances used to kill, foil, mitigate or deter the effects of pests and encompasses a broad range of insecticides, herbicides, rodenticides, algicides, fungicides and bactericides (FAO and WHO, 2015). They serve majorly as economic poisons intended to control target species. Sadly, it has been estimated that, only about $0.1 \%$ of applied pesticides get to the target pests while the residual $99.9 \%$ become a function of toxicity to non-target species in terrestrial and especially aquatic ecosystems (Pimentel, 1995). This has raised concerns about their toxicity to man and his environment, thereby prompting several studies. To assess in a more realistic way, the potential impact of a specific pesticide on a specific organism, it is important to have the knowledge of the biological and ecological relationship of that species 
and their ecosystem function. The approach used in this study spans from the hypothesis that, "if organisms can detect food, individuals of same species and potential predators, perhaps, they could as well detect chemical signals from contaminants, hence, flee to lesser disturbed habitats (Araújo \& Blasco, 2019).

Dichlorvos and Paraquat, both of which due to their toxicity and environmental impacts were outlawed from the European Union since 1998 and 2007 respectively, are still applied widely in large scale agriculture in many developing countries like Nigeria. They find their way into aquatic environments through runoffs, wind or through uncontrolled waste disposal (Mazlan et al., 2017). Dichlorvos is notable for its ability to irreversibly inhibit acetylcholinesterase (AChE) enzyme by degrading acetylcholine, a neurotransmitter in the cholinergic synapse of living organisms (Varó et al., 2008) and has shown to cause mortality at a range of 0.2 to $12 \mathrm{mg}$ $\mathrm{L}^{-1}$ to fresh water and estuarine fish (Roth, 2000). However, the $96 \mathrm{~h} \mathrm{LC}_{50}$ has been estimated to be greater than $4 \mathrm{mg} \mathrm{L}^{-1}$ for adults and pre-adults of Atlantic salmon (Salmo salar) (Varó et al., 2008). Paraquat on the other hand is a member the viologen salts, a group of compounds that is known for their redox-active properties. Commercialized under different brand names in developing countries (Arivu et al., 2015), Paraquat is known to be extremely toxic to fauna, lethally affecting the liver, lungs and kidneys if ingested. Paraquat is also known to cause mortality to Raspora trilineats, Clarias gariepinus, Orechromis niloticus and Luciobarbus esocimus (Seiyaboh et al., 2013).

The spatial avoidance and habitat preference responses measured in non-forced, multi-compartmented exposure systems, which was developed by Lopes et al. (2004) has proven to be consistent in representing how spatial displacements can be driven by contamination gradients. Several authors have reported using this approach in demonstrating how various contaminants can cause spatial avoidance in organisms such as fishes, amphibians, decapods, copepods, annelids, crustaceans, and dipterans (Moreira-Santos et al., 2008; Ren et al., 2009; Rosa et al., 2012; Araújo et al., 2014a; 2014b, 2014c, 2016a; Silva et al., 2017; Ehiguese et al., 2019). Daphnia magna (Cladocera) avoided the organochlorine pesticide, chlorthalonil (Ren et al., 2009); Danio rerio when exposed to gradients of the inorganic pesticide, copper sulphate (Moreira-Santos et al., 2008); Litopenaeus vannamei (decapod) exposed to copper sulphate (Araújo et al., 2016a). Also, In-situ experiments by Átland \& Barlaup (1995) have also shown a preferential distribution avoiding disturbed and contaminated habitats by fish.

Oreochromis niloticus of the family Cichlidae and genius Oreochromis is the most widely and commercially grown fish in Nigeria and across tropical and subtropical regions of the world. It has high tolerance for poor water quality, spawns easily and is cultured extensively both for food, economic as well as experimental purposes. They are also known to play a limnological role in the circulation of nutrients on which primary productions in water bodies hang (Beauchamp, 1964). However, the risks that arises from pollutants such as pesticides which presents toxic and behavioural changes including spatial displacements of exposed populations, threaten severe ecological consequences if unchecked. So, in order to meticulously model in a more realistic way the behavioural endpoint of pesticides on fish and its imminent ecological importance, the present study was designed. Existing studies have focused mainly on the toxicological effects of pesticides to Nile tilapia which have all been carried out under forced exposure conditions without offering an alternative for exposed organisms to escape and present avoidance. Therefore, the ability of $O$. niloticus to detect and avoid contamination by moving towards less contaminated zones is of high importance to Ecology. This is because it presents possible changes concerning the displacement patterns of the organisms especially given that the approach used in this study have been scarcely investigated. Hence, this study evaluated the potential of Dichlorvos and Paraquat to elicit avoidance as a behavioural indices in an exposed population of the Nile tilapia (O. niloticus) with the aim of understanding in a more realistic way, how they contribute to population decline as well as other ecological implications.

\section{MATERIALS AND METHODS}

\section{Test animal and laboratory acclimatization}

Nile Tilapia (Oreochromis niloticus) fries (age 6-8 days) were obtained from a fish farm in Lagos State, Nigeria and transported to the Ecotoxicology and Conservation unit Laboratory, University of Lagos, in a plastic tank half-filled with pond culture water. The organisms were relocated into a $40 \mathrm{~L}$ capacity holding tank $(1 \mathrm{x} \mathrm{w} \mathrm{x} \mathrm{h}=60 \mathrm{~cm} \times 35 \mathrm{~cm} \mathrm{x}$ $30 \mathrm{~cm}$ ) in the laboratory half filled with dechlorinated water and a 220-v air pump (Cosmo aquarium air pump- double type 12000) was used to provide aeration in order to maintain levels of dissolved oxygen in the holding tank. The holding tank was cleaned and culture water renewed every 48 hours to prevent accumulation of toxic waste metabolites (Otitoloju, 2006). Average mean weights and length of the fishes were $6.72 \pm 0.43 \mathrm{~g}$ and $2.0 \pm 0.3 \mathrm{~cm}$ respectively. The fishes were acclimatized to laboratory conditions for a period of 7 days prior to exposure (based on OECD Test 203 Guideline) during which they were fed with Coppens ${ }^{\circledR}$ fish feed containing $45 \%$ crude protein, provided daily at $1 \%$ of body weight. The mean physico-chemical parameters of culture water in the holding tank were measured using a Horiba U50 water quality monitor. The parameters measured were; dissolved oxygen $7.1 \mathrm{mg} \mathrm{L}^{-1}$, $\mathrm{pH} 7.65$, salinity $0.01 \mathrm{ppt}$, total dissolved solids $144 \mathrm{mg} \mathrm{L}^{-1}$ and specific conductance of $24.56 \mu \mathrm{S} / \mathrm{cm}$. Fishes were exposed to their natural photoperiod ( $12 \mathrm{~h}$ daylight and $12 \mathrm{~h}$ darkness). Feeding of fishes stopped $24 \mathrm{~h}$ before exposure.

\section{Test chemicals}

The test chemical used were; Sniper, an emulsifiable concentrate (EC) containing $1000 \mathrm{~g} \mathrm{~L}^{-1}$ DDVP (Dichlorvos) 
manufactured by Forward (Beihai) Hepu Pesticide Co. Ltd, Beihai, Guangxi, China and ParaeForce, manufactured by Nanjing Redsun Biochemistry Co. Ltd, Nanjing City, China (active ingredient $276 \mathrm{~g}$ of Paraquat dichloride, $200 \mathrm{~g}$ Paraquat). Both chemicals were Purchased from Everbright Industries Limited Mushin, Lagos State, Nigeria and stored at room temperature prior to bioassay. They are among the most commonly purchased pesticides used by farmers in Nigeria based on interview with agrochemical vendors and farmers in three major markets in Lagos (Ojota, Yaba and Mushin).

\section{Non-Forced Multi-Compartmented System for Avoidance}

A multi-compartmented static exposure system (Figure 1) as described by Araújo et al., (2014c) was used in the avoidance assays. Four systems were constructed each consisting six compartments made from plastic bottles joined at the cut-out bases and mouths using plastic glue (Zuma PVC glue, Ogun, Nigeria) to obtain a six-compartment system. The top of each compartment was also cut open to facilitate the introduction of pesticides and fishes.

The avoidance system was calibrated using $\mathrm{NaCl}$ solution (Araujo et al., 2014c). This was performed in order to confirm the stability of the contamination gradient $(\mathrm{y}=0.115+0.776 \mathrm{x}$; $\left.r^{2}=0.9741 ; r=0.9869 ; p<0.00001 ; n=3\right)$. Concentrations $\left(0.2,0.4,0.6,0.8\right.$ and $\left.1 \mathrm{~g} \mathrm{~L}^{-1}\right)$ of $\mathrm{NaCl}$ were prepared using dechlorinated tap water. Plasticine plugs wrapped in parafilm were used to isolate each compartment and the prepared solutions were transferred into each compartment to form a linear concentration gradient. The plasticine plugs were subsequently removed to begin calibration in the absence of organisms. The calibration process was conducted in quadruplet, under laboratory conditions and lasted $3 \mathrm{~h}$ corresponding with the maximum time that would be used during exposure assay with organisms. Conductivity was measured before and after calibration and the initial $(0 \mathrm{~h})$ and final (3h) values were recorded in each compartment.

\section{Acute Toxicity testing (Forced exposure)}

Preliminary tests were carried out at first to determine suitable range concentration for the bioassay.

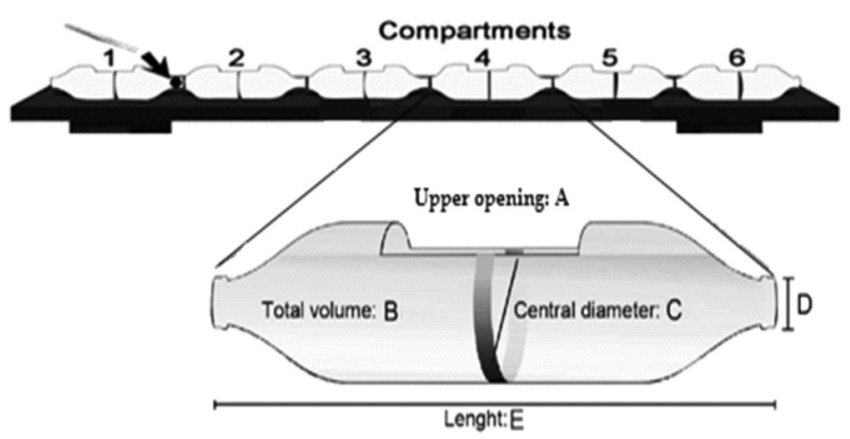

Figure 1: Schematic diagram of the non-forced multi-compartmented exposure system used in the avoidance experiments with Oreochromis niloticus exposed to concentrations of dichlorvos and paraquat: $\mathrm{A}=8 \times 6$ $\mathrm{cm} ; \mathrm{B}=1500 \mathrm{~mL} ; \mathrm{C}=9 \mathrm{~cm} ; \mathrm{D}=2 \mathrm{~cm} ; \mathrm{E}=31 \mathrm{~cm}$.
Concentrations derived and used were; Dichlorvos: 1.0, 2.0, 4.0, 5.0, and $6.0 \mathrm{mg} \mathrm{L}^{-1}$; Paraquat: 10, 30, 50, 70, 100 $\mathrm{mg} \mathrm{L}^{-1}$. Each concentration was carefully measured into a bioassay aquarium $(1 \mathrm{x} \mathrm{w} \mathrm{x} \mathrm{h}=6 \mathrm{~cm} \times 6 \mathrm{~cm} \times 7 \mathrm{~cm})$ for each agrochemical. Three (3) active fishes were randomly selected from the holding tank and introduced into each glass aquaria laced with the contaminant as well as in control (free of contaminants). Each treatment of agrochemicals was in quadruplicate totaling 12 fishes per treatment. Exposed fishes were monitored for mortality at $24,48,72$, and 96 hours. Fish were not fed during the experiment (Reish et al., 1986) and were confirmed dead by their failure to respond to stimulus even when prodded gently with a glass rod. All experiments were conducted under the same laboratory conditions as acclimatization.

\section{Avoidance Assessment (Non-forced exposure)}

Prior to exposures in the presence of contaminants, a control assay was carried out without contaminants to further validate the non-interference of external factors on the random distribution of fish along the compartments (without preference for any compartment). The compartments were each filled with $1 \mathrm{~L}$ of freshwater after which three active tilapias were added into each compartment totaling 18 fishes per system. The distribution of the fishes was recorded at each $20 \mathrm{~min}$ for $3 \mathrm{~h}$ and tests were performed in quadruplicate making 72 fishes.

The contaminant gradients used for avoidance exposures with Dichlorvos and Paraquat were in the order of 0 (freshwater), 1.0, 2.0, 4.0, 5.0 and 6.0 $\mathrm{mg} \mathrm{L}^{-1}$ for Dichlorvos and $0,10,30,50,70,100 \mathrm{mg} \mathrm{L}^{-1}$ for Paraquat. For each avoidance test with the contaminants, plasticine plugs were fitted at the connecting junctions of each compartment before filling them with freshwater spiked with Dichlorvos and Paraquat. After the gradients were established, three $(n=3)$ active tilapias were introduced into each compartment (18 fishes per system) and plasticine plugs subsequently removed. The distribution of organisms in the systems was observed and recorded at each $20 \mathrm{~min}$ for $3 \mathrm{~h}$. Tests were conducted in quadruplicate and in the dark to prevent interference of external factors.

\section{Statistical analysis}

The stability of the $\mathrm{NaCl}$ gradient was analyzed by comparing the initial and final concentrations observed after 3 hours, using a linear regression model (R-squared goodness of fit). A one-way analysis of variance (ANOVA) was carried out followed by a post hoc (LSD and Tukey multiple comparison test $(p<0.05))$ test to ensure there was no overlap in the concentrations of $\mathrm{NaCl}$ along the systems.

The results from acute tests were analyzed by Probit regression analysis as described by Finney (1971), to calculate the lethal concentration values for each individual test chemical used. As such, the toxicity indices measured were $\mathrm{LC}_{50}$, corresponding confidence intervals and toxicity factor (TF). 
The percentage distribution of organisms in all experiments were arcsine transformed and analyzed using mixed-designed analysis of variance (ANOVA) with time as a repeated measure, within factor and compartment as between factor (Ehiguese, et al., 2019). To check sphericity, Mauchly's test was employed, and where sphericity was debased (where variance of the differences was not equal: $p<0.05$ ), Greenhouse-Geisser correction was applied. Bonferonmi test was applied when there was statistical $(\mathrm{p}<0.05)$ difference between factors.

For avoidance from Dichlorvos and Paraquat, the percentage avoidance was calculated as the difference between the number of expected fishes $\left(\mathrm{N}_{\mathrm{E}}\right)$ and number of observed alive fishes $\left(\mathrm{N}_{\mathrm{O}}\right)$ (Moreira-Santos et al., 2008) i.e., Avoiders $=\mathrm{N}_{\mathrm{E}}-\mathrm{N}_{\mathrm{O}}$. The number of expected fishes $\left(\mathrm{N}_{\mathrm{E}}\right)$ represents the original number of fishes introduced into each compartment. This means that, for the first compartment (compartment with highest concentration of contaminant), $\mathrm{N}_{\mathrm{E}}$ was 3 since three organisms were initially introduced. For the next compartment, $\mathrm{N}_{\mathrm{E}}$ was 6 (3 fishes originally introduced plus 3 fishes from the adjacent compartment). For the sixth compartment (only freshwater), $\mathrm{N}_{\mathrm{E}}$ was 18 , meaning that a zero percent avoidance is expected in the uncontaminated compartment. The percentage avoidance for each compartment was calculated as (Avoiders $\left./ \mathrm{N}_{\mathrm{E}}\right) * 100$. The recorded percentage avoidance was used in obtaining the $\mathrm{AC}_{50}$ values (concentration causing avoidance by $50 \%$ of the exposed organisms) and the corresponding $95 \%$ confidence interval using Probit regression analysis.

The PID $x$ ( $x$ in percent) was calculated by integrating avoidance and mortality, using $y$ mortality percentage (i.e., the $96 \mathrm{~h} \mathrm{LCy}$ ) and a $w$ avoidance percentage (i.e., the 3-h $\mathrm{AC} w)$, as described by Rosa et al. (2012): $\mathrm{X}=[1-(1-y / 100)$ $*(1-w / 100)] * 100$.

The $\mathrm{PID}_{50}$ values (the concentration causing a population immediate decline of $50 \%$ of the exposed organisms) and the corresponding Confidence Interval (CI) were also obtained. All statistical analysis was performed using the SPSS Version 23 software (IBM).

\section{RESULTS}

\section{Validation of avoidance system}

Both avoidance assays were validated in order to meet acceptance criteria i.e., to ensure that the contamination gradient in the systems are maintained in the absence of organisms, using $\mathrm{NaCl}$ and to ensure no preference is given to compartments by the tested organisms using culture water with no contamination gradient. The $\mathrm{NaCl}$ gradient in the experimental system was maintained and remained stable over the 3 hours experimental period. Also, a significant difference was observed in the $\mathrm{NaCl}$ concentrations between compartments (LSD and Tukey Multiple Comparison Test: F $(5,18)=755.02, \mathrm{p}<0.00001)$.

In the control experiment without contaminants, the hypothesis of random distribution of fishes along a homogeneous uncontaminated system without preference for any compartment was supported. No statistical difference was observed in tilapia distribution between the six compartments after $3 \mathrm{~h}\left(\mathrm{~F}_{5,18}=1.19, \mathrm{p}=0.228\right)$. The mean percentage distribution of fish in each compartment in control experiment is presented in Figure 2.

\section{Acute Toxicity}

The dose-response relationship (Forced exposure) for Dichlovros and Paraquat indicated that tilapia responded in a dose-dependent manner after 96-h of exposure. The highest concentration of exposure for both pesticides (Dichlorvos: 6.0 mg L-1 and Paraquat: $100 \mathrm{mg} \mathrm{L}^{-1}$ ) induced $66.67 \%$ and $83.33 \%$ mortalities respectively while lowest concentrations $(1 \mathrm{mg}$ $\mathrm{L}^{-1}$ and $10 \mathrm{mg} \mathrm{L}^{-1}$ ) resulted in $16.67 \%$ and $0 \%$ mortality at 96 h. The 96-h $\mathrm{LC}_{50}$ values recorded for Dichlorvos and Paraquat were $3.86 \mathrm{mg} \mathrm{L}^{-1}$ and $50.67 \mathrm{mg} \mathrm{L}^{-1}$ correspondingly (Table 1). On the bases of the estimated $96-\mathrm{h} \mathrm{LC}_{50}$ values, Dichlorvos was 13 times more toxic than Paraquat. Abnormal stress behaviours

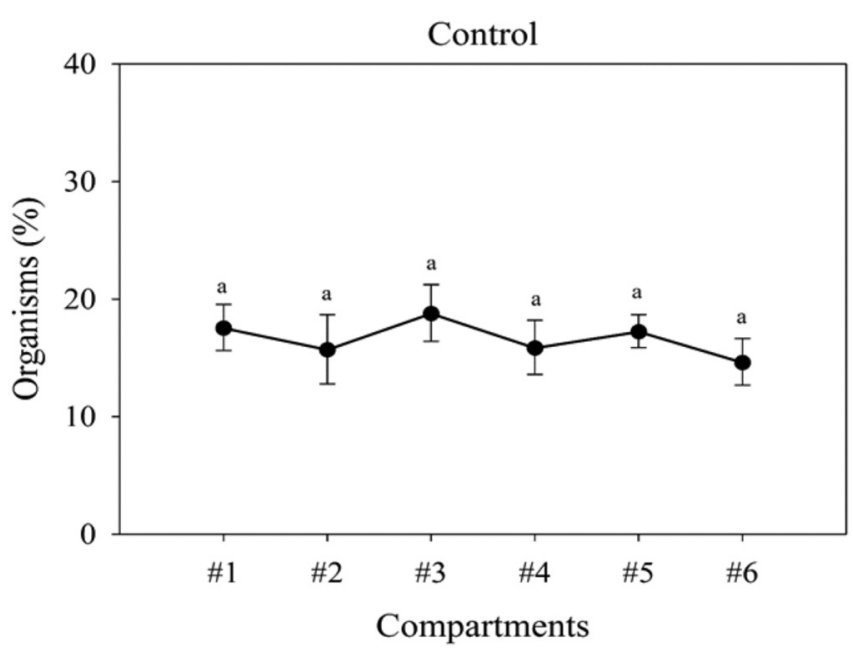

Figure 2: Mean percentage distribution and standard deviation $(\mathrm{n}=9$ observation periods) of the number of Oreochromis niloticus fry in the culture water during control tests and observed per compartment over $3 \mathrm{~h}$. Letters indicate statistically significant differences.

Table 1: Single action $96 \mathrm{~h}$ Toxicity indices of Dichlorvos and Paraquat acting against Oreochromis niloticus.

\begin{tabular}{lccccc}
\hline Pesticide & $\mathrm{LC}_{50}(95 \% \mathrm{CI})$ & Slope $\pm \mathrm{SE}$ & Probit line Equation & $\mathrm{DF}$ & $\mathrm{TF}$ \\
\hline Dichlorvos $(\mathrm{mg} / \mathrm{L})$ & $3.86(2.44-8.80)$ & $1.86 \pm 0.64$ & $\mathrm{Y}=-1.07+1.82 \mathrm{x}$ & 3 & 1 \\
Paraquat $(\mathrm{mg} / \mathrm{L})$ & $50.67(36.64-67.42)$ & $3.37 \pm 0.89$ & $\mathrm{Y}=-5.29+312 \mathrm{x}$ & 3 & 13.13
\end{tabular}

CI: Confidence Interval, DF: Degree of Freedom, SE: Standard Error, TF: Toxicity Factor 
such as erractic swimming, secretion of mucus, gulping of air, restlessness and loss of balance, were observed during tests.

\section{Avoidance response and population immediate decline (PID)}

Mortality did not occur in either of the non-forced experiments with each pesticide. The relative frequency of fishes distributed in each compartment and significant differences for each pesticide are shown in Figure 3. There was statistically significant preference for uncontaminated compartments by fishes exposed to both Dichlorvos $\left(\mathrm{F}_{5,18}\right.$ $=48.058, \mathrm{p}<0.005)$ and Paraquat $\left(\mathrm{F}_{5,18}=135.358, \mathrm{p}<\right.$ $0.005)$. The distribution also varied significantly $(\mathrm{p}<$ $0.05)$ over time. The mean percentage distribution of $O$. niloticus exposed to gradients of Dichlorvos and Paraquat after $3 \mathrm{~h}$ was $41.42 \%$ and $79.63 \%$ correspondingly, in the uncontaminated compartment $\left(0 \mathrm{mg} \mathrm{L}^{-1}\right)$ which was over 24 times more than that recorded in compartments with the highest concentrations $\left(6 \mathrm{mg} \mathrm{L}^{-1}: 1.73 \%\right.$ and $100 \mathrm{mg} \mathrm{L}^{-1}$ : $1.85 \%$ for Dichlorvos and Paraquat respectively).

The avoidance, PID (in \%) and mortality for exposed fishes are shown in Figure 4. The avoidance distribution was concentration dependent for both pesticides. Due to the absence of mortality in non-forced exposures, the PID curve followed same trend as the avoidance curve. Avoidance was least in the lowest compartments $\left(1 \mathrm{mg} \mathrm{L}^{-1}: 40 \%\right.$ and $10 \mathrm{mg} \mathrm{L}^{-1}: 90 \%$ for Dichlorvos and Paraquat respectively) and increased to $100 \%$ for both pesticides in compartments with the highest concentration $\left(6 \mathrm{mg} \mathrm{L}^{-1}\right.$ and $100 \mathrm{mg} \mathrm{L}^{-1}$ for Dichlorvos and Paraquat respectively).

\section{Estimated $A C_{50}, L C_{50}$, and PID}

The estimated $\mathrm{AC}_{50}, \mathrm{LC}_{50}$, and $\mathrm{PID}_{50}$ (considering forced and non-forced exposure data) values for Dichlorvos and
Paraquat are shown in Table 2. The $\mathrm{AC}_{50}$ values (from nonforced experiments) obtained for Dichlorvos and Paraquat were $1.36 \mathrm{mg} \mathrm{L}^{-1}$ and $2.3 \mathrm{mg} \mathrm{L}^{-1}$, respectively, and their corresponding $\mathrm{LC}_{50}$ values (from forced exposure tests) were $>6.0 \mathrm{mg} \mathrm{L}^{-1}$ and $>100 \mathrm{mg} \mathrm{L}^{-1}$. Since there was no mortality in the non-forced tests, the $\mathrm{AC}_{50}$ was equal to $\mathrm{PID}_{50}$. The $\mathrm{AC}_{50}$ values from non-forced exposures were very similar to the $\mathrm{PID}_{50}$ of forced exposures, however, it was about 3 and 22 times lower than the corresponding $\mathrm{LC}_{50}$ (forced exposure) values for Dichlorvos and Paraquat.

\section{DISCUSSION}

The present study measured the toxicity potential of Pesticides (Dichlorvos and Paraquat) and their ability to provoke avoidance responses among exposed populations of $O$. niloticus using a multi-compartmented non-forced

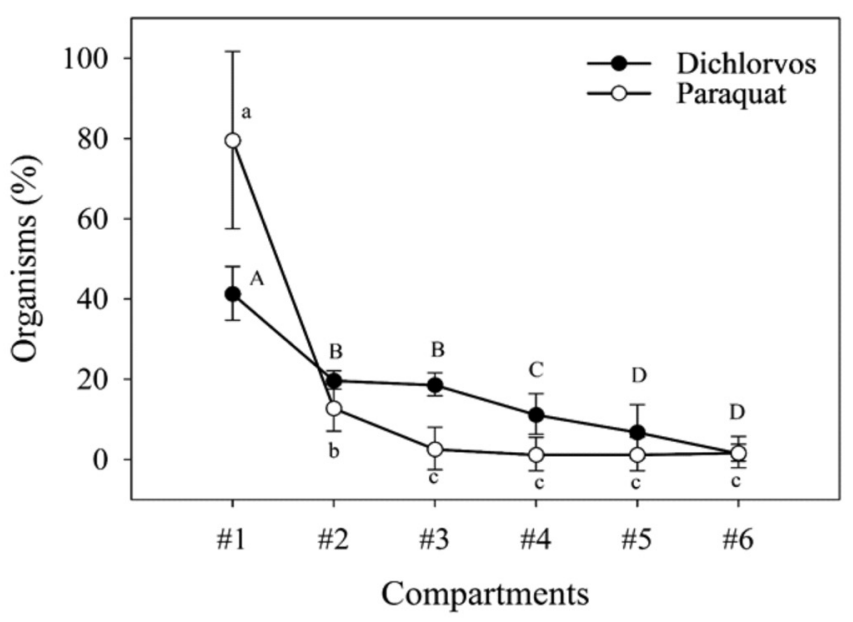

Figure 3: Mean percentage distribution and standard deviation $(\mathrm{n}=9$ observation periods of 2 mins each) of Oreochromis niloticus exposed to contamination gradients of Dichlorvos and Paraquat recorded in each compartment for $3 \mathrm{~h}$. Different letters (Upper case for Dichlorvos and lower case for Paraquat) indicate statistically significant differences.

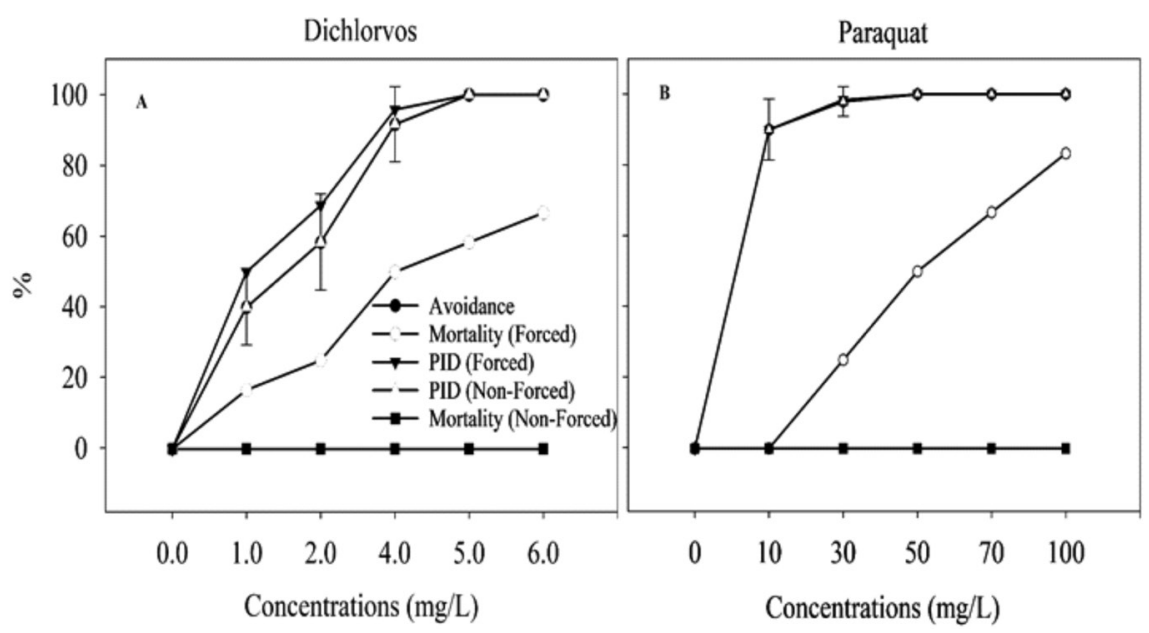

Figure 4: Concentration-response curves for avoidance (non-forced exposure) and mortality (forced exposure) responses, and the estimated PID of Nile tilapia Oreochromis niloticus exposed to gradients of Dichlorvos (A) and Paraquat (B). Standard deviations were not presented for forced exposures, because the mortality was calculated based on number of exposed organisms. 
exposure system. The result from forced exposures revealed that Dichlorvos and Paraquat were both acutely toxic to Nile tilapia after $96 \mathrm{~h}$ exposure.

The 96- $\mathrm{h} \mathrm{LC}_{50}$ value $\left(3.86 \mathrm{mg} \mathrm{L}^{-1}\right)$ recorded in the present study for Dichlorvos was very similar to those observed by Varo et al. (2008) who recorded $\mathrm{LC}_{50}$ values of $3.5 \mathrm{mg} \mathrm{L}^{-1}$ and $3.17 \mathrm{mg} \mathrm{L}^{-1}$ when Dicentrarchus labrax and Aphanius iberus were exposed to the same pesticide. Saha et al. (2016), however, recorded a slightly lower $\mathrm{LC}_{50}$ value $\left(2.8 \mathrm{mg} \mathrm{L}^{-1}\right)$ when Mozambique tilapia (Oreochromis mossambicus) were exposed to Dichlorvos. Behavioural deviations of fishes exposed to Dichlorvos include restlessness, erratic swimming and jumping which could have resulted from the inactivation of acetylcholinesterase, leading to accumulation of acetylcholine at synaptic junctions of the fishes (Varo et al, 2008).

For Paraquat, the observed $\mathrm{LC}_{50}$ value $\left(50.67 \mathrm{mg} \mathrm{L}^{-1}\right)$ from the present study was very similar to $54.66 \mathrm{mg} \mathrm{L}^{-1}$ observed for Luciobarbus esocinus fingerlings (Alishahi et al., 2016). However, it was about four times higher than $12 \mathrm{mg} / \mathrm{L}$ observed for O. niloticus (Babatunde \& Oladimeji, 2014). This variation could be a result of different environmental conditions of exposure and the wide concentration range used in the present study. However, Paraquat has long been classified as "slightly toxic" to freshwater fishes, with 96-h $\mathrm{LC}_{50}$ varying with species from 13 - $156 \mathrm{mg} \mathrm{L}^{-1}$ (USEPA, 2009). Abnormal stress behaviours observed such as erractic swimming, secretion of mucus, gulping of air, restlessness and loss of balance was in agreement with the findings of Omitoyin et al. (2006).

The result from the control tests in the non-forced exposure system showed that $O$. niloticus did not present avoidance or fondness for any compartment as fish distribution was random thereby validating the use of the system. This conforms with observations made by Araújo et al. (2016b) who observed that Tilapia. spp distribution pattern did not statistically change when exposed to uncontaminated freshwater. In separate studies with other organisms, distribution pattern was random and non-preferential in control assays with culture water only using similar multi-compartmented non-forced exposure system. (Araújo et al., 2014b, 2014c, 2014d; Silva et al., 2017; Ehiguese et al., 2019).

Fingerlings of $O$. niloticus showed ability to detect and significantly avoid lethal and sublethal gradients of Dichlorvos and Paraquat contaminants. This proves that in a realistic scenario, Nile Tilapia will present avoidance behaviour from contamination as long as there is option to escape. At the lowest concentrations $\left(1 \mathrm{mg} \mathrm{L}^{-1}\right.$ and $10 \mathrm{mg} \mathrm{L}^{-1}$ for Dichlorvos and Paraquat respectively), O. niloticus presented $40 \%$ and an incredible $90 \%$ avoidance correspondingly after $3 \mathrm{~h}$, implying that organisms can detect low level contamination and significantly avoid them over the shortest period of time. This observation is in agreement with studies performed using similar non-forced systems with varying pollutant gradients to assess contamination-driven spatial displacements. For example, around $50 \%$ of exposed zebrafish (Danio rerio) population avoided $1.4 \mathrm{mg} \mathrm{L}^{-1}$ of the fungicide Pyrimethanil (Araújo et al., 2014d, 2014b). The repellents DEET and EBAAP were recorded to cause continuous drift at $33 \mu \mathrm{g} \mathrm{L} \mathrm{L}^{-1}$ to exposed Amphipoda (Gammarus pulex), Ephemeroptera (Cloeon dipterum) using indoor stream mesocosms (Fink et al., 2017). About $60 \%$ and $57 \%$ avoided $0.05 \mathrm{mg} \mathrm{L}^{-1}$ when the estuarine shrimps Palaemon varians were exposed to gradients of musk fragrances Galaxolide and Tonalide under nonforced multi-compartmented exposure systems (Ehiguese et al, 2019). Also, 22\% of Poecilia. reticulata exposed to triclosan gradient avoided concentrations as low as $0.2 \mathrm{mg} \mathrm{L}^{-1}$ (Silva et al., 2017). In view of $\mathrm{AC}_{50}$ values, previous studies also showed that environmental relevant concentrations can be avoided by exposed organisms. Notably, Silva et al. (2017) observed that $P$. reticulata exposed to a bisphenol gradient was able to avoid contamination as low as $0.15 \mathrm{mg} \mathrm{L}^{-1}$ which is below the value considered environmentally safe for aquatic ecosystems. Avoidance is evidently a response of great importance especially in environmental situations where a contamination gradient occurs (Silva et al., 2017). This is because, 'other than the disruption of food webs brought by the desertion of contaminated habitats by escaping organisms, avoidance response can also lead to the establishment of metapopulations (Araújo \& Blasco, 2019). Hence the ecological impact of the present result should not be limited to the avoided ecosystem (Ehiguese et al., 2019). This comes as $O$. niloticus is known to be one of the most widespread invasive fish species owing to its rapid reproduction ability, thereby, exerting competition pressure on native fishes of the new habitat (Gu et al., 2015). Other ecological impacts include eutrophication of inhabited waterbodies due to rapid consumption of phytoplankton (Figueredo and Giani, 2005), hybridization with native fishes (Ellender \& Weyl, 2014) and predation on amphibians and juveniles of other fish species (Zambrano et al., 2006), which presents a damaging structure of native food webs.

The PID was estimated by integrating mortality and avoidance responses. This was done in order to explain the short-term impact of dispersed contamination to Tilapia on a local scale. Avoidance being more sensitive than mortality was clearly the response that played a more pertinent role in the PID at all concentrations. Fishes completely (100\%) avoided the highest concentrations (6 $\mathrm{mg} \mathrm{L}^{-1}$ and $100 \mathrm{mg} \mathrm{L}^{-1}$ for Dichlorvos and Paraquat respectively) of contaminants which caused the greatest number of mortalities

Table 2: Concentrations in $\mathrm{mg} / \mathrm{L}$ (and their respective $95 \%$ intervals in $\mathrm{mg} / \mathrm{L}$ ) of Dichlorvos and Paraquat that cause avoidance $\left(\mathrm{AC}_{50}\right)$, mortality $\left(\mathrm{LC}_{50}\right)$ and population immediate decline ( $\mathrm{PID}_{50}$ ) of $50 \%$ of exposed populations of Orechromis niloticus.

\begin{tabular}{lccccc}
\hline Pesticide & $\mathrm{AC}_{50}(\mathrm{NFS})$ & $\mathrm{LC}_{50}(\mathrm{NFS})$ & $\mathrm{PID}_{50}(\mathrm{NFS})$ & $\mathrm{LC}_{50}(\mathrm{FS})$ & $\mathrm{PID}_{50}(\mathrm{FS})$ \\
\hline Dichlorvos & $1.355(1.08-1.61)$ & $>6$ & $1.355(1.08-1.61)$ & $3.86(2.44-8.80)$ & $1.08(0.81-1.32)$ \\
Paraquat & $2.29(0.002-5.374)$ & $>100$ & $2.295(0.002-5.374)$ & $50.67(36.64-67.42)$ & $2.56(0.00-5.63)$
\end{tabular}

NFS: Non-forced System; FS: Forced System 
(66.67\% and $83.33 \%$ correspondingly) in forced exposures. This implies that, whenever the locomotor, nervous and chemoreceptor systems are not impaired, fish generally show a clear preference for inhabiting areas with small or no contamination (MoreiraSantos et al., 2008; Araújo \& Blasco, 2019; Ehiguese et al., 2019). However, some authors noted that other environmental toxicants can weaken the swimming ability of fish, hence, possibly damaging their ability to present avoidance (Chen et al., 2007; Denoël et al., 2013) consequently subjecting them to the lethal potential of such toxicants. Cases of stupefaction and moribundity of exposed organisms under non-forced conditions have also been reported by some authors (Araújo et al., 2014c; Silva et al., 2017).

The present study reaffirmed the acute toxicity of Dichlorvos and Paraquat to $O$. niloticus even at low concentrations under forced circumstances. Nevertheless, $O$. niloticus proved to be able to detect and avoid even sublethal concentrations of both pesticides under non-forced exposure conditions. Consequently, avoidance was a more sensitive response and played a greater role in the decline of the exposed population. For this reason, the integration of both approaches is strongly recommended (Rosa et al., 2012; Araújo et al., 2016a, 2017; Araújo \& Blasco, 2019) as a complimentary tool in ecological risk assessment. Additional studies are also required to measure the environmental consequences of the present results, in order not to overestimate the lethality of forced exposures hence misjudging the true extent of population decline in a more realistic scenario.

\section{ACKNOWLEDGEMENT}

The authors wish to appreciate the Department of Zoology, University of Lagos for providing the bench space and reagents for this research work.

\section{REFERENCES}

ALISHAHI, M., TULABY DEZFULY, Z., \& MOHAMMADIAN, T. 2016. Acute toxicity evaluation of five herbicides: paraquat, 2, 4-dichlorophenoxy acetic acid (2, 4-D), trifluralin, glyphosite and atrazine in Luciobarbus esocinus fingerlings. Iran. J. Vet. Res., 10(4): 319 - 330. https://dx.doi.org/10.22059/ ijvm.2016.59726

ARAUJO, C.V.M., MOREIRA-SANTOS, M., SOUSA, J.P., OCHOA-HERRERA, V., ENCALADA, A.C., \& RIBEIRO, R. 2014a. Active avoidance from a crude oil soluble fraction by an Andean paramo copepod. Ecotoxicology, 23: 1254-1259. https://doi.org/10.1007/s10646-015-1599-1

ARAUJO, C.V.M., SHINN, C., MENDES, L.B., DELELLOSCHENEIDER, D., SANCHEZ, A.L, \& ESPNDOLA, E. L.G. 2014b. Avoidance response of Danio rerio to a fungicide in a linear contamination gradient. Sci. Total Environ., 484: 36-42. https://doi.org/10.1016/j.scitotenv.2014.03.037

ARAUJO, C.V.M., SHINN, C., MOREIRA-SANTOS, M., LOPES, I., ESPNDOLA, E. L. G., \& RIBEIRO, R. 2014c. Copperdriven avoidance and mortality in temperate and tropical tadpoles. Aquat. Toxicol., 146: 70-75. https://doi.org/10.1016/j. aquatox.2013.10.030

ARAUJO, C.V.M., SHINN, C., VASCONCELOS, A.M., RIBEIRO,
R., \& ESPNDOLA, E.L.G. 2014d. Preference and avoidance responses by tadpoles: The fungicide pyrimethanil as a habitat disturber. Ecotoxicology, 23: 851-860. https://doi.org/10.1007/ s10646-014-1225-7

ARAUJO, C.V.M., CEDENO-MACIAS L.A., VERA-VERA, V.C., SALVATIERRA, D., RODRIGUEZ E.N.V., ZAMBRANO, U., \& KURI, S. 2016a. Predicting the effects of copper on local population decline of 2 marine organisms, cobia fish and white leg shrimp, based on avoidance response. Environ. Toxicol. Chem., 35: 405-410. https://doi.org/10.1002/etc.3192

ARAÚJO, C.V.M., RODRÍGUEZ, E.N.V., SALVATIERRA, D., CEDENO-MACIAS, L.A., VERA-VERA, V.C., MOREIRASANTOS, M., \& RIBEIRO, R. 2016b. Attractiveness of food and avoidance from contamination as conflicting stimuli to habitat selection by fish. Chemosphere, 163: 177-183. https:// doi.org/10.1016/j.chemosphere.2016.08.029

ARAÚJO, C.V.M. \& BLASCO, J. 2019. Spatial avoidance as a response to contamination by aquatic organisms in non-forced, multi-compartmented exposure systems: a complementary approach to the behavioral response. Environ. Toxicol. Chem., 38: 312-320. https://doi.org/10.1002/etc.4310

ARIVU, I., MUNIYAN, M., MUTHULINGAM, M., PARTHIBAN, P., AMBEDKAR, G., \& KAMALKANTH, S. 2015. Toxicity of 2, 4-Dichlorophenoxyacetic acid on freshwater fingerlings Labeo rohita (Hamilton). World. J. Pharm. Pharm. Sci., 4: 1173-1190.

ÅTLAND, Å. \& BARLAUP, B.T. 1995. Avoidance of toxic mixing zones by Atlantic salmon (Salmo salar L.) and brown trout (Salmo trutta L.) in the limed river Audna, southern Norway. Environ. Pollut., 90(2): 203-208. https://doi.org/10.1016/02697491(95)00002-9

BABATUNDE, M.M., \& OLADIMEJI, A.A. 2014. Comparative study of Acute toxicity of Paraquat and Galex to Oreochromis niloticus. Int. J. Adv. Sci., 4(3): 437-444.

BEAUCHAMP, R.S.A. 1964. The Rift Valley Lakes of Africa. Internationale Vereinigung für theoretische und angewandte Limnologie: Verhandlungen, 15(1): 91-99. https:// doi.org/10.1080/03680770.1962.11895508

CHEN, T.H., GROSS, J.A., \& KARASOV, W.H. 2007. Adverse effects of chronic copper exposure in larval northern leopard frogs (Rana pipiens). Environ. Toxicol. Chem., 26: 1470-1475. https://doi.org/10.1897/06-487R.1

DENOËL, M., LIBON, S., KESTEMONT, P., BRASSEUR, C., FOCANT, J-F., \& DE PAUW, E. 2013. Effects of a sublethal pesticide exposure on locomotor behavior: A video-tracking analysis in larval amphibians. Chemosphere, 90: 945-951. https://doi.org/10.1016/j.chemosphere.2012.06.037

EHIGUESE, F.O., FERNANDEZ, M.D.C.C., LARA-MARTIN, P.A., MARTIN-DIAZ, M.L., \& ARAÚJO, C.V.M. 2019. Avoidance behaviour of the shrimp Palaemon varians regarding a contaminant gradient of galaxolide and tonalide in seawater. Chemosphere, 232: 113-120. https://doi.org/10.1016/j. chemosphere.2019.05.196

ELLENDER, B.R. \& WEYL, O.L.F. 2014. A review of current knowledge, risk and ecological impacts associated with non-native freshwater fish introductions in South Africa. Aquat. Invasions, 9(2): 117-132. http://dx.doi.org/10.3391/ ai.2014.9.2.01

FAO, \& WHO. 2015. International Code of Conduct on Pesticide Management. Guidelines on Pesticide Legislation. Retrieved from http://www.fao.org/3/a-i5008e.pdf

FIGUEREDO, C.C. \& GIANI, A. 2005. Ecological interactions between Nile tilapia (Oreochromis niloticus, L.) and the phytoplanktonic community of the Furnas Reservoir (Brazil). Freshw. Biol., 50: 1391-1403. https://doi.org/10.1111/j.13652427.2005.01407.x

FINK, P., MOELZNER, J., BERGHAHN, R., \& VON ELERT, E. 
2017. Do insect repellents induce drift behaviour in aquatic nontarget organisms? Water Research, 108: 32-38.

FINNEY, G. J. 1971. Probit Analysis ( $3^{\text {rd }}$ Edition) Cambridge press, London U.K., 318p.

GU, D.E., MA, G.M., ZHU, Y.J., XU, M., LUO, D., LI, Y.Y., WEI, H., MU, X.D., LUO, J.R., \& HU, Y.C. 2015. The impacts of invasive Nile tilapia (Oreochromis niloticus) on the fisheries in the main rivers of Guangdong Province, China. Biochem. Syst. Ecol., 59: 1-7.

LOPES, I., BAIRD, D.J., \& RIBEIRO, R. 2004. Avoidance of copper contamination by field populations of Daphnia longispina. Environ. Toxicol. Chem., 23: 1702-1708. https://doi. org/10.1897/03-231

MAJEED A. 2018. Application of Agrochemicals in Agriculture: Benefits, Risks and Responsibility of Stakeholders. J. Food Sci. Toxicol., 2: 11

MAZLAN, N., AHMED, M., MUHARAM, F.M, \& ALAM, M.A. 2017. Status of persistent organic pesticide residues in water and food and their effects on environment and farmers: a comprehensive review in Nigeria. Semina: Ciências Agrárias, 38(4): 2221-2236. http://dx.doi.org/10.5433/1679$0359.2017 \mathrm{v} 38 \mathrm{n} 4 \mathrm{p} 2221$

MOREIRA-SANTOS, M., DONATO, C., LOPES, I., \& RIBEIRO, R. 2008. Avoidance tests with small fish: Determination of the median avoidance concentration and of the lowest-observed effect gradient. Environ. Toxicol. Chem., 27: 1576-1582. https:// doi.org/10.1897/07-094.1

OMITOYIN, B.O., ADESINA, B.T., AJANI, E.K., \& OKUAGU, C.N.F. 2006. Toxicity of lindane (gamma hexachlorocyclohexane) to Clarias gariepinus (Burchell 1822). World J. Zool., 1(1): 57-63.

OTITOLOJU, A. A. 2006. Joint action toxicity of spent lubrication oil and laundry detergent against Poecilia reticulata (Telostei: Poeciliidae). Afr. J. Aquat. Sci., 31(1): 125-129. https://doi. org/10.2989/16085910609503879

PIMENTEL, D. 1995. Amounts of pesticides reaching target pests: environmental impacts and ethics. J. Agric. Environ. Ethics, 8: 17-29. https://doi.org/10.1007/BF02286399

REISH, D.J., OSHIDA, P.S., MEARNS, A.J., \& GINN, T.C. 1986. Effects on saltwater organisms. Journal (Water Pollution Control Federation), 58(6): 671-684.

REN, Z., LI, Z., MA, M., WANG, Z., \& FU, R. 2009. Behavioral responses of Daphnia magna to stresses of chemicals with different toxic characteristics. Bull. Environ. Contam. Toxicol., 82(3): 310-316.

ROSA, R., MATERATSKI, P., MOREIRA-SANTOS, M., SOUSA,
J.P., \& RIBEIRO, R. 2012. A scaled-up system to evaluate zooplankton spatial avoidance and population immediate decline concentration. Environ. Toxicol. Chem., 31: 1301-1305. https:// doi.org/10.1002/etc. 1813

ROTH, M. 2000. The availability and use of chemotherapeutic sea lice control products. Contrib. Zool., 69(1-2): 109-118. http:// dx.doi.org/10.1163/18759866-0690102012

SAHA, N.C., GIRI, S.K., CHATTERJEE, N., BISWAS, S.J., \& BEJ, S. 2016. Acute toxic effects of mancozeb to fish Oreochromis mossambicus (WKH Peters, 1852) and their behaviour. Int. J. Adv. Res. Biol. Sci., 3: 40-44.

SEIYABOH, E.I., INYANG, I.R., GIJO, A.H. \& ADOBENI, G.D. 2013. Acute Toxicity of Paraquat Dichloride on Blood Plasma Indices of Clarias gariepinus. J. Environ. Sci. Toxicol. Food Tech., 7(6): 15-17.

SILVA, D.C.V.R., ARAÚJO, C.V.M., JULIO, C.L., NETO, M.B., SILVA, T., PAIVA, T.C.B., \& POMP, M.L.M. 2017. Potential effects of triclosan on spatial displacement and local population decline of the fish Poecilia reticulata using a non-forced system. Chemosphere, 184: 329-336. https://doi.org/10.1016/j. chemosphere.2017.06.002

SMITH, H. AND BAILEY, C. 1990. Preference/avoidance testing of waste discharges on anadromous fish. Environ. Toxicol., 9: 77-86. https://doi.org/10.1002/etc.5620090110

TILMAN, D., FARGIONE, J., WOLFF, B., D'ANTONIO, C., DOBSON, A, HOWARTH, R., ... SWACKHAMER, D. 2001. Forecasting agriculturally driven global environmental change. Science (New York, N.Y.), 292(5515), 281-284. https://doi. org/10.1126/science. 1057544

USEPA (Environmental Protection Agency). 2009. Risk of Paraquat Use to Federally Threatened California Red-legged frog (Rena aurora draytonii). Pesticide Effects Determination. Environmental Fate and Effects Division, of! Ce of pesticides programs, US Enironmental Protection Agency, Washington, D.C.

VARÓ, I., AMAT, F., \& NAVARRO, J.C. 2008. Acute toxicity of dichlorvos to Aphanius iberus (Cuvier \& Valenciennes, 1846) and its anti-cholinesterase effects on this species. Aquat. Toxicol., $\quad 88(1), \quad 53-61 . \quad$ https://doi.org/10.1016/j. aquatox.2008.03.004

ZAMBRANO, L., MARTÍNEZ-MEYER, E., MENEZES, N., \& PETERSON, A.T. 2006. Invasive potential of common carp (Cyprinus carpio) and Nile tilapia (Oreochromis niloticus) in American freshwater systems. Canadian Can. J. Fish. Aquat. Sci., 63: 1903-1910. https://doi.org/10.1139/f06-088. 